\title{
Design of Straight Bevel Gear for Pitting Resistance
}

\author{
Edward E. Osakue \\ Department of Industrial Technology \\ Texas Southern University \\ Houston, Texas, \\ USA \\ Lucky Anetor \\ Department of Mechanical Engineering \\ Nigerian Defence Academy \\ Kaduna, \\ Nigeria
}

Based on the Tredgold geometric approximation, a transparent contact stress capacity model for straight bevel gears is presented. A bevel load factor is defined which provides a kinetic link between the physical bevel gear and virtual spur gear. Three design cases of contact stress computations from different references are carried out and compared with AGMA estimates. Differences in results vary from $2.4 \%$ to $23.4 \%$ with the new model estimates, generally lower than AGMA values. The design sizing version of the new model is applied in two design cases. Comparison of the service load factor values for design sizing and design verification indicates a difference of $0.76 \%$ in case 4 and $-1.65 \%$ in case 5. While more design cases are necessary for further verification of the design approach presented, it may however, be concluded from the results of our study that the design model presented appears reasonable.

Keywords: Bevel gear, Geometric equivalence, Virtual spur gear, Kinetic, Contact stress, Failure, Pitting

\section{INTRODUCTION}

Bevel gears have teeth cut on the frustum of a cone instead of a cylinder as for spur and helical gears. In order for two cones to roll without sliding, they must have a common apex. Hence bevel gears must be properly mounted on shafts so that the elements of the gear teeth converge into an apex [1]. This ensures that the pitch surfaces of two meshing bevel gears are proportional to the distance from the common apex. Consequently, pure rolling of the meshing bevel gears is possible. Because the pitch surfaces of bevel gears are conical, the teeth cut on them vary in thickness and height from the front end to the back end. That is, the tooth profile at the front end or toe is smaller in size than that at the back end or heel, the larger end of bevel gears. It is standard practice in bevel gear technology to define the size and shape of the tooth profile at the back end [2].

Generally, bevel gears are more difficult to manufacture and assemble compared to spur and helical gears. Special tools and machines are required to cut their teeth [3]. They are usually not inter-changeable because tooth form is closely tied to the method used in manufacturing them, so they are made and replaced as matched gearsets of pinion and gear. Considerable axial forces are developed in bevel gear meshes, hence elaborate bearing arrangement is need-ed for their proper support. However, numerous machines and mechanisms require use of intersecting shafts therefore bevel gears are widely used in engineering practice [3]. The shaft angle most commonly used for transmitting power between intersecting shafts is $90^{\circ}$ but it could be different.

Received: October 2017, Accepted: December 2017

Correspondence to: Dr. Edward E. Osakue

Department of Industrial Technology

Texas Southern University, Houston, USA

E-mail: osakueee@tsu.edu

doi:10.5937/fmet18021940

(C) Faculty of Mechanical Engineering, Belgrade. All rights reserved
Bevel gears are widely used in gearboxes [4-6].

The common types of bevel gears are straight, spiral, zero, and hypoid bevel gears [6], but the straight bevel gear is the most popular. The teeth of straight bevel gears are straight on the conical disk surface. They are easier to design and manufacture, compared to other bevel gears and give reasonable service life when properly mounted. Normal speed ratio for straight bevel gears is up to 4 but may be as high as 6 . However, they generate noise at high-speed conditions [1]. Where smoothness and quietness are not very important, straight bevel gears can be used up to a pitch point velocity of $5 \mathrm{~m} / \mathrm{s}$. But ground bevel gears could be used up to $75 \mathrm{~m} / \mathrm{s}$ while ground spiral bevel gears could be used up to $125 \mathrm{~m} / \mathrm{s}$ [4]. The most popular pressure angle is $20^{\circ}$. However, $22.5^{\circ}$ and $25^{\circ}$ pressure angles are used in heavy-duty drives [7] and often in the automotive industry [2]. Bevel gears with $14.5^{\circ}$ and $17.5^{\circ}$ may be found also $[2,8]$. Pressure angles of $20^{\circ}$ and higher are often used to avoid interference [6]. The International Standardization Organization (ISO) pressure angle standard is the $20^{\circ}$ which is more attractive for international collaboration and commerce. The minimum number of teeth suggested for a bevel gear pinion is 12 [6]. Care should be taken to provide rigid mountings and stiff shafts when using bevel gears. The greatest rigidity is obtained when both gears are straddle mounted which ensures proper alignment of teeth during power transmission [6].

The two prominent modes of gear failure are surface fatigue or pitting and bending fatigue, but the present focus is on the former. Pitting is the development of local minute surface depressions or pits on surfaces of objects in rolling and sliding contact under repeated load applications. Pitting resistance or durability is the capacity of a gearset to operate for an acceptable duration without pitting. Gear failure may be caused by transmission error, design error, manufacturing error and assembly error. Generally, severe surface wear out 
in gears is caused by higher contact stresses coupled with lower lubrication film between two mating gears and the presence of debris in the lubricant $[5,9]$.

The contact or surface fatigue strength of bevel gears is closely related to the surface hardness of the gear like other types of gears. The nominal contact fatigue strength is adjusted through modification factors when estimating the service contact strength. American Gear Manufacturers Association (AGMA) has extensive data on gear material properties and recommends methods for estimating service contact strengths. Similarly ISO has developed methods for estimating service contact strength of gears of different material types. Steel is the most popular gear material and heat treated steel gears may be categorized into thruhardened and case-hardened gears. The surface and core hardness values of thru-hardened gears are approximately the same but case-hardened gears have different core and case hardness values. Thru-hardened gears have hardness values in the approximate range of 180 to 450 HVN (Hardness: Vicker's Number). They are good up to about $425 \mathrm{HVN}$, above which they become brittle and fail more easily by tooth breakage than gears of lower hardness [10]. Case-hardened steel gears have hardness values in the approximate range of 450 to 1000 HVN and generally have 30 to $50 \%$ higher contact strength than thru-hardened gears [10]. Case-hardened bevel gears often have surface hardness of 700 to 770 VHN and a core hardness of 300 to $400 \mathrm{VHN}$ [11]. Distortion is experienced after hardening and hard finishing is done to correct this. Face run-out is a problem with bevel ring gears.

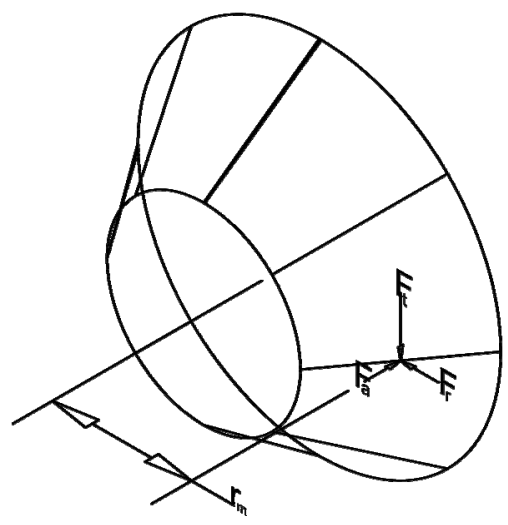

a) 3D force representation

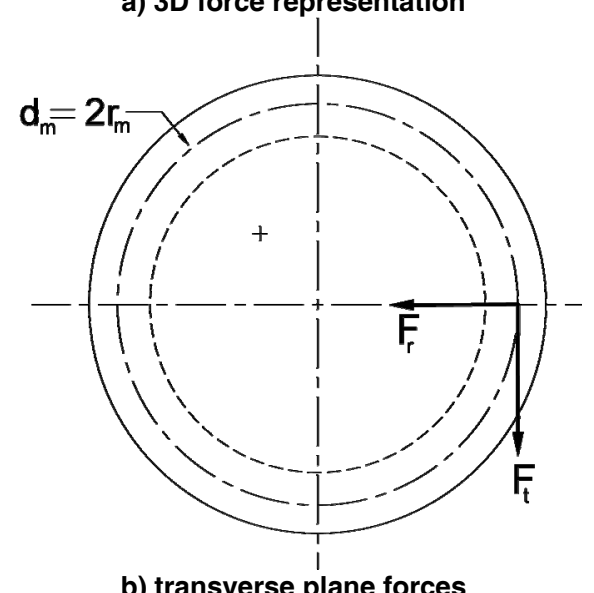

b) transverse plane forces

Fig. 1: Bevel gear force components
The non-iterative all-acoustic method is based on TDOA principle described by the system of 4 non-linear equations. Solving this system gives PD location. Transformer is observed in the Cartesyan space (Fig. 1). Each sensor has coordinates $x_{S i}, y_{S i}, z_{S i}(i=1, . .4)$, while the location of the partial discharge source is marked by coordinates $x, y, z$. The velocity of acoustic signal propagation $v_{s}$ is considered to be constant, while the problem of acoustic signal propagation through materials other than transformer oil is disregarded. Figure 1 shows the appearance of acoustic signals of partial discharge recorded by four acoustic sensors $S_{1}, S_{2}, S_{3}$, $S_{4}$. It illustrates the acoustic signal time delays $\tau_{12}, \tau_{13}$, $\tau_{14}$ between sensors $S_{1}$ and $S_{2}, S_{1}$ and $S_{3}$, as well as $S_{1}$ and $S_{4}$ where $T_{1}<T_{2}<T_{3}<T_{4}$. The time from discharge occurrence to sensor's $S_{l}$ response, $T_{l}$, is unknown. Distances between PD source and sensors $l_{i}, i=1 . .4$, refer to $l_{1}<l_{2}<l_{3}<l_{4}$.

Since the non-iterative mathematical algorithm relies solely on acoustic measurements, it is not necessary to conduct additional electrical or other measurements of partial discharge activities. This algorithm does not have a solution convergence problem. In the field, this method can be applied to transformers in the operating mode, by using only four acoustic sensors mounted on the transformer wall. Since one measurement is sufficient for successful partial discharge detection, the partial discharge source does not need to be active over a lengthy period of time.

\section{BEVEL GEAR FORCES}

In the design analysis of bevel gears, the load is commonly assumed to be applied at the mid-face width. Actually, the resultant forces act somewhere between the midpoint and the back end of the tooth width [13]. This means the force components used in design analysis are slightly over-rated, so that the stresses and reaction forces based on them are similarly slightly conservative. It should be noted that the complexities of the tooth profile of bevel gears make precise analysis rather very complicated and such a conservative approach is justified.

Fig. 1a depicts a bevel gear under load with the three components of the contact force shown at the mid-plane pitch point. In a bevel, $F_{t}$ acts parallel to the cone angle on the gear tooth. Fig. $1 \mathrm{~b}$ shows the transverse plane at the mid-plane pitch point which is obtained by looking in the direction of the shaft axis. The pitch diameter of the bevel gear at this point is indicated. This plane may be called the transverse kinetic plane since the operating tangential and radial force components on the physical bevel gear are defined on this plane. The axial kinetic plane is not shown but contains the tangential and axial force components. The tangential force is the driving force, the radial and axial forces are generated due to the gear pressure angle and the cone pitch angle for bevel gears.

The torque load on the pinion is:

$$
T_{1}=\frac{30 P_{1} \times 10^{3}}{\pi N_{1}}
$$

Please refer to the nomenclature section for the definition of symbols. The actual gear ratio for a gearset is: 


$$
\mu=\frac{T_{2}}{T_{1}}=\frac{N_{1}}{N_{2}}=\frac{z_{2}}{z_{1}}
$$

The contact stress capacity model developed is based on the transmitted torque and not the transmitted tangential force conventionally used. This is informed by the fact that at the beginning of a gear design problem, the transmitted power and the rotational speed of the input or output shaft may be known or can be estimated. Hence the input or output torque may be estimated. Sometimes the transmitted torque may be specified altogether.

The transmitted force is:

$$
F_{t}=\frac{2 T \times 10^{3}}{r_{m 1}}=\frac{2 T \times 10^{3}}{r_{m 2}}
$$

In bevel gears, the radial distance to a point on the cone from the shaft axis in the transverse plane is a linear function of the distance of that point from the apex of the cone. Therefore:

$$
\frac{r_{m}}{r_{e}}=\frac{m}{m_{e}}=\frac{L}{L_{e}} \quad d_{m}=d_{e}\left(\frac{L}{L_{e}}\right)
$$

Then:

$$
d_{m}=\frac{d_{e}}{K_{b}} \quad K_{b}=\frac{L_{e}}{L}=\frac{L_{e}}{L_{e}-0.5 b}
$$

Substitute Eq. (5a) in Eq. (3):

$$
F_{t}=\frac{2 K_{b} T_{1} \times 10^{3}}{d_{e 1}}=\frac{2 K_{b} T_{2} \times 10^{3}}{d_{e 2}}
$$

The other forces are:

$$
\begin{aligned}
& F_{n}=\frac{F_{t}}{\cos \varphi} \\
& F_{r}=F_{t} \tan \varphi \cos \phi \quad F_{a}=F_{t} \tan \varphi \sin \phi
\end{aligned}
$$

\section{SPUR GEAR GEOMETRIC EQUIVALENCE}
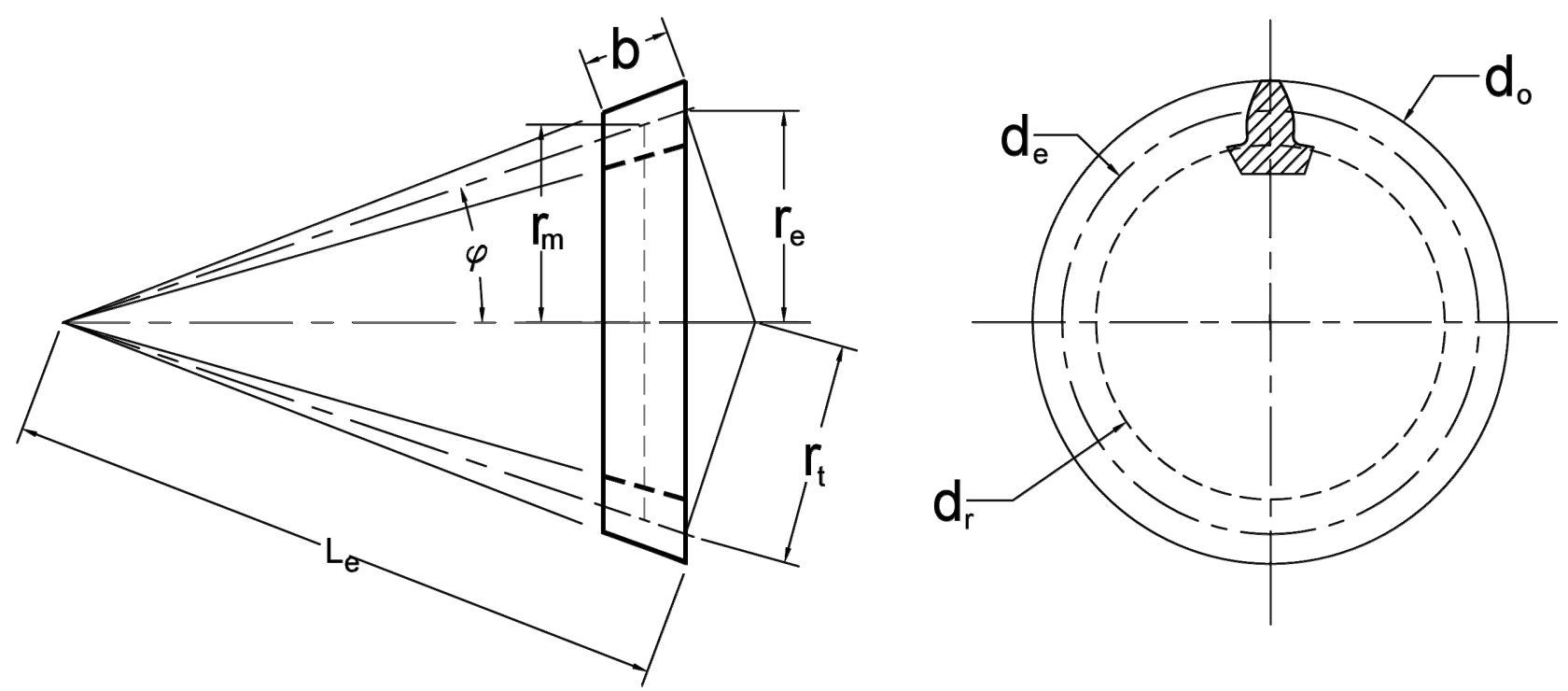

Bevel gears have a spherical geometry, so the involute tooth profile should be developed on a spherical surface to ensure conjugate action. However, it is not possible to develop a spherical involute profile on a plane and if that was possible, it would be impractical to manufacture [2]. Since the contact fatigue (pitting wear) and bending fatigue (beam) strengths of gears are based on the involute tooth profile, it is necessary practically, to approximate bevel gear tooth profile as accurately as possible. The "Tredgold's approximation" is commonly accepted and it uses the cone tangent to the sphere at the back end pitch point. Such a cone is found geometrically to closely approximate the surface of the sphere. Thus in bevel gear technology, the back cone tangent to the theoretical sphere at the pitch radius is used to develop a plane surface on which the tooth profile is created. In a plane normal to the pitch cone similar to those of spur gears [14]. The back-cone radius of the bevel gear then becomes the radius of an imaginary or virtual spur gear with teeth and pressure angle corresponding to the bevel gear. Hence the basic shape of a bevel gear tooth is almost the same as that of this spur gear $[2,13]$. Therefore the manufacturing dimensions of a bevel gear are based on the back end module which is largely standardized.

Fig. 2a shows the axial plane of a straight bevel gear while Fig. 2b shows the transverse plane at the back end. The basic physical gear size parameters are shown in these figures, except the module. Figs. $3 \mathrm{a}$ and $3 \mathrm{~b}$ show the geometrically equivalent or virtual spur of a bevel gear. The tooth profile of a spur gear lies in the transverse plane. Similarly, the tooth profile of the virtual spur gear for a bevel gear lies in the transverse plane. It should be noted that the virtual spur gear pitch circle diameter maps onto the back end cone of the physical bevel gear, not the tooth mid-width cone where operating forces and velocity are evaluated. Conceptually, it is important to separate the physical bevel gear from the virtual spur gear to avoid confusion in the kinetic relationship between the two objects. angle or contact line, meshing bevel gears appear to be a) Axial plane
Fig. 2: Physical bevel Gear b) Transverse plane 


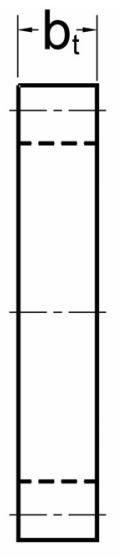

a) Axial plane

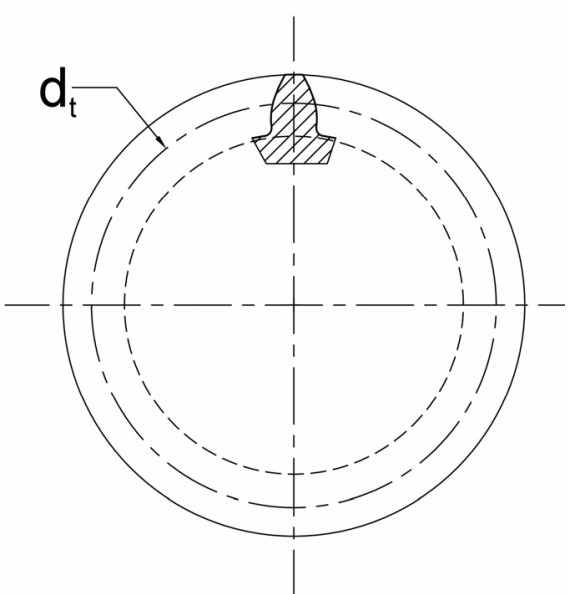

b) Transverse plane

\section{Fig. 3: Virtual spur Gear}

The Tredgold's approximation is a geometric equivalence only which should be noted by comparing Fig. 1b with Fig. 3b. The geometric parameters and sizes are different for these figures. Moving from the plane of Fig. $1 \mathrm{~b}$ to the plane of Fig. $3 \mathrm{~b}$ involves a rotational motion of the gear or shaft axis through the cone pitch angle and a translational motion from the face width midpoint to the back end of the bevel gear to get to the location of the plane of Fig. $3 \mathrm{~b}$. The view of Fig. $3 b$ is obtained by looking at the back end in the direction of the cone pitch angle.

The angle between the center lines of the shafts carrying the bevel gears is called the shaft angle. A shaft angle of $90^{\circ}$ is the most popular in use but other angles are sometimes used. When the shaft angle is $90^{\circ}$, the bevel gearset is called right-angle drive; otherwise it is called oblique-angle drive. Bevel gear meshing must be considered in pairs because the pitch cone angles are restricted by the gear ratio [14]. That is:

$$
\phi_{0}=\phi_{1}+\phi_{2}
$$

With reference to [14] and after some simplification, the cone pitch angles are obtained as:

$$
\tan \phi_{1}=\frac{\sin \phi_{o}}{\mu+\cos \phi_{o}} \quad \tan \phi_{2}=\frac{\mu \sin \phi_{o}}{1+\mu \cos \phi_{o}}
$$

The radius and diameter of the virtual spur gear are, respectively:

$$
r_{t}=\frac{r_{e}}{\cos \phi} \quad d_{t}=\frac{d_{e}}{\cos \phi}
$$

The gear ratio of the virtual spur gear is:

$$
\mu_{t}=\frac{d_{t 2}}{d_{t 1}}=\frac{d_{e 2} \cos \phi_{1}}{d_{e 1} \cos \phi_{2}}=\mu \frac{\cos \phi_{1}}{\cos \phi_{2}}
$$

\section{DESIGN VERIFICATION FOR CONTACT FATIGUE}

The objective in design verification is to assess the adequacy of a design. Based on the result(s) of design sizing, the designer(s) have size(s) which can be used to estimate stresses or other performance capacities of

a component or assembly. The performance capacity result(s) can then be judged for acceptability based on a design factor or reliability target. If the evaluated design factor or reliability level for a failure mode is smaller or lower that a minimum value, the design is deemed inadequate otherwise it is accepted. A common performance capacity for gears is contact fatigue or pitting resistance which is one of the two prominent modes of gear failure $[2,15,16]$. Fatigue failure is due to crack formation and propagation induced by repeated loading. At increased gear speed, the prospects for pitting and scoring failure modes in gears increase. The German physicist, Henry Hertz developed expressions for the stresses created when objects with curved frictionless surfaces are loaded in contact in 1881. Thus contact stresses are generally called Hertz stresses and his solution is the basis of pitting resistance design in gearing technology. Pitting occurs in gears when the contact strength of the meshing flanks is exceeded, resulting in crack growth followed by particle breakout from the flanks [15]. It is believed that a shear stress initiated crack beneath the surface due to excessive repeated Hertz contact stresses gradually develops to the tooth surface and causes shearing away of some materials thus leaving a pit behind. Pitting generally appears first at or below the pitch point on the pinion tooth $[2,13,17]$. In addition to contact stress, pitting is influenced by sliding velocity, lubricant viscosity, and friction [13]. For maximum durability, it is desirable to distribute the wear uniformly amongst all gear teeth [18].

The Hertz contact stress in line contact when applied to bevel gear is given [19] as:

$$
\begin{aligned}
& \sigma_{H}=\sqrt{\frac{F_{n} E_{c} \times 10^{3}}{\pi \rho_{t} b_{t}}} \\
& E_{c}=\frac{2 E_{1} E_{2}}{E_{2}\left(1-v_{1}^{2}\right)+E_{1}\left(1-v_{2}^{2}\right)} \\
& \rho_{t}=\frac{2 r_{t 2} r_{t 1} \sin \varphi}{r_{t 2} \pm r_{t 1}}=\frac{d_{t 2} \sin \varphi}{\mu_{t}+1} \quad b_{t}=b
\end{aligned}
$$

Eq. (18) is the theoretical model for the Hertz contact stress on the virtual spur gearset when the forces and pitch point velocity are evaluated at the mid-width of the actual bevel gear. Note that the forces at the pitch point on the virtual spur gears are different from those on the physical bevel gears determined at the mid-with pitch point. That is, the Tredgold's approximation is a geometric equivalence and not a kinetic one.

Now for a straight bevel gear of perfect geometry, perfectly manufactured and assembled in a perfect housing, Eq. (18) should be a good approximation. In the real world of engineering practice, tolerances on gear and housing sizes are required due to manufacturing imperfections; errors in assembling and installation may be present, and unbalanced rotating and or reciprocating masses create internal vibrations, etc. Therefore, the actual or service loads on gears are generally higher than the rated values. Hence for practical applications, the service load on a gear may 
be expressed as the rated load multiplied by a service load factor $K_{s}$. Also, bevel gears are manufactured with good enough accuracy to permit some load sharing action during transmission [8]. So a load sharing factor $\varpi_{s}$ is appropriate in the contact stress estimate above. Means of estimating $K_{s}$ and $\varpi_{s}$ are briefly presented in the Appendix.

The factor $K_{f}$ was defined as contact form factor for cylindrical gears $[19,22]$ based on line contact model which creates a rectangular contact patch, theoretically. However, manufacturing and assembly inaccuracies create contact patches that deviate in shape from that of a rectangle. Sometimes crowning is applied to gear teeth and this promotes localized contact stress for-mation [20]. Specifically, the contact patch in bevel gears is an elongated ellipse [21]. For these reasons, $K_{f}$ will be defined here as contact stress factor and Eq. (17) modified as:

$$
K_{f}=\frac{2 K_{e}}{\pi \sin 2 \varphi}
$$

The factor $K_{e}$ is introduced to account for contact shape deviation from rectangular, as is expected for line contact. For example $K_{e} \approx 1.5$ for elliptical shape factor is reported by Collins [2]. Norton [20] stated a crowning factor of 1.0 for uncrowned teeth and 1.5 for crowned teeth for straight bevel gears. Note that Eq. (17) is a special case of Eq. (19) when $K_{e}$ has a value of unity, as in uncrowned cylindrical gears.

In cognizance of the three issues highlighted with respect to $\varpi_{s}, K_{s}$ and $K_{f}$ above, Eq.(18) is modified for engineering applications as:

$\sigma_{H}=\left[\frac{2 K_{f} K_{b} K_{s}\left(\mu_{t}+1\right) \cos \phi_{2} E_{c} T_{1}}{\varpi_{s} b d_{e 1} d_{e 2}}\right]^{\frac{1}{2}} \times 10^{3}$

Eq. (19) is the new general contact stress model for straight bevel gears which may be described as transparent since it explicitly reflects the principal design parameters that are used to estimate the Hertz contact stress in straight bevel gears. This brings some simplicity in bevel gear design as the "I" parameter in AGMA model is eliminated. The basic dimensions of the gearset in the model can be evaluated once initial sizes are determined. Design sizing addresses the estimation of an initial back end module in the next section.

A gearset design is accepted as adequate or satisfactory when:

$$
S_{H}=\frac{S_{c}}{n_{c}} \quad \sigma_{H} \leq S_{H}
$$

Alternatively:

$$
n_{H}=\frac{S_{c}}{\sigma_{H}} \quad n_{H} \geq n_{c}
$$

\section{DESIGN SIZING FOR CONTACT FATIGUE}

In design sizing calculations, simplifying assumptions are made to obtain initial sizes for components and assemblies in the normal iterative design process.
Generally, design sizing capacity model should be based on the most significant failure mode of a com-ponent in order to obtain a reasonable initial size [23]. A reasonable estimate of size in design sizing task should result in fewer iterations during design verifi-cation [24]. Now, the basic size parameter for bevel gears is the module at the back end. Design sizing task should therefore provide an initial estimate of this parameter from which other gear dimensions can be evaluated.

\subsection{Pinion Teeth Number}

Generally $z_{1}+z_{2} \geq 32$ for $20^{\circ}$ pressure angle and if space limitation is not a design concern, let $z_{1} \geq 25$ for straight bevel gears [3]. It is recommended that $z_{1} \geq 25$ if noise is a concern. Normally, $z_{1}$ should be in the range of 18 to 30 but could be lower, depending on the speed ratio. If no specific conditions are given, then for straight bevel gears, it is suggested that:

$$
z_{1} \geq \max (15,26-1.5 \mu)
$$

\subsection{Gear Face Width}

For straight-bevel, spiral-bevel and hypoid gears, face width should be limited to $25-30 \%$ of cone distance [2]. Based on the $30 \%$ restriction, it can be shown that:

$$
\lambda_{b} \leq 0.15 \sqrt{\mu_{o}^{2}+1}
$$

Now:

$$
d_{e 1}=m_{e} z_{1} \quad d_{e 2}=\mu_{o} m_{e} z_{1} \quad d_{e 2}=\mu_{o} m_{e} z_{1}
$$

Considering the fact that the service load factor $K_{s}$ can be evaluated only approximately at the beginning of a gear design task, it will be replaced with $K_{s}^{\prime}$, its approximate value. Substitute Eq. (24) into Eq. (19) to obtain Eq. (25):

$$
\sigma_{H}^{2}=\frac{2 K_{b} K_{s}^{\prime} K_{f}\left(\mu_{t o}+1\right) \cos \phi_{2} E_{c} T_{1} \times 10^{6}}{\varpi_{s} \mu_{o} \lambda_{b} z_{1}^{3} m_{e}^{3}} \leq S_{H}^{2}
$$

The back end module is determined from Eq. (26) as:

$$
m_{e} \geq \frac{100}{z_{1}}\left[\frac{2 K_{b} K_{s}^{/} K_{f}\left(\mu_{t o}+1\right) \cos \phi_{2} E_{c} T_{1}}{\mu_{o} \varpi_{s} \lambda_{b} S_{H}^{2}}\right]^{1 / 3}
$$

In Eq. (26), $E_{c}$ and $S_{H}$ are gear material properties and can be evaluated once gear materials and heat treatment methods are decided on. The only design parameter needed if not included in the gearset design specifications is the external overload factor $K_{O}$. This can be selected from AGMA [25] tables or other similar design data reference sources. The use of reference tables or charts is therefore largely eliminated in Eq. (26). This is an improvement and a good simplification in preliminary design.

\subsection{Basic Gear Dimensions}

Based on the estimate of Eq. (26), a standard module size should be chosen. The pinion teeth used for gear 
module estimate may be reduced if selected standard module is larger than the estimated value. Similarly, it may be increased if selected standard module is smaller than the estimated value. The number of gear teeth should be estimated and an integer value chosen. That is:

$$
z_{2} \approx \mu_{o} z_{1} \quad \mu=\frac{z_{2}}{z_{1}}
$$

Choosing a higher or smaller module value than estimated allows a designer to reduce or increase $z_{1}$ and $z_{2}$ while keeping $\mu$ constant. When a hunting tooth is used in power drives, the speed ratio deviation should be checked. That is:

$$
\epsilon_{o}=\frac{100\left(\mu-\mu_{o}\right)}{\mu_{o}}
$$

For power transmission gearing, the AGMA recommended speed deviation $\left(\in_{o}\right)$ are $\pm 3 \%$ for singlestage reduction, $\pm 4 \%$ for double- and triple-stage reduction and $\pm 5 \%$ for quadruple-stage reduction [26]. The value of $\epsilon_{o}$ for control gears should ideally be zero.

Once the speed deviation is acceptable and the gear teeth number is chosen, the basic dimensions of the gearset can be obtained as given in Eqs. (29) and (30).

$$
\begin{aligned}
& d_{e 1}=m_{e} z_{1} d_{e 2}=m_{e} z_{2} \\
& b \leq \lambda_{b} d_{e 1} \\
& b_{2}=b b_{1} \leq b_{2}+5 \mathrm{~mm}
\end{aligned}
$$

\section{DESIGN MODEL CAPACITY VERIFICATION}

The new design contact stress capacity model of Eq. (20) is tested in three design cases which involve the determination of contact stress values, a design verification task. The problem statements in the design cases have been paraphrased and the design parameters have been converted to metric units where necessary by the authors. The results from the new model are compared with AGMA contact stress values.

The equations presented in the previous sections were coded in Microsoft Excel for computational efficiency. The spreadsheet has two pages of two sections per page. The first page has a material selection and strengths estimation sections. The second page has design sizing and design verification sections. Iteration during design verification can be done by changing the values of effective face width, gear module, and gear teeth.

\subsection{Design Case 1}

A right-angle bevel gearset made of steel transmits 5.25 $\mathrm{kW}$ with the pinion running at $1150 \mathrm{rpm}$. The following data apply to the gears: $K_{O}=1.0, z_{1}=18, \mathrm{z} 2=59, b=$ $38.1 \mathrm{~mm}, \mathrm{~m}_{\mathrm{e}}=4.23 \mathrm{~mm}$, and $q_{n}=9$ [2, p 670 - 674]. What is the expected contact stress on the gearset?

\subsection{Design Case 2}

A right-angle bevel gearset made of steel transmits 7.5 $\mathrm{kW}$ with the pinion running at $2500 \mathrm{rpm}$. The following data apply to the gears: $K_{O}=1.0, z_{1}=20, z_{2}=35$, $b=21.34 \mathrm{~mm}, m_{e}=3.18 \mathrm{~mm}$, and $q_{n}=11$ [20, p. $776-$ 778]. What is the expected contact stress on the gearset?

\subsection{Design Case 3}

A right angle bevel gearset made of steel transmits 1.86 $\mathrm{kW}$ with the pinion running at $600 \mathrm{rpm}$. The following data apply to the gears: $K_{O}=1.5, z_{1}=16, z_{2}=48, b=$ $25.4 \mathrm{~mm}, m_{e}=3.18 \mathrm{~mm}$, and $q_{n}=11$ [6, p $\left.472-474\right]$. What is the expected contact stress on the gearset?

\subsection{Solutions: Cases 1 to 3}

Table 1 summarizes the basic gearset dimensions and load data for cases 1 to 3 for contact stress computation. Table 2 shows the AGMA contact stress values in column 2 as determined in the referred works and the new model contact stress values are in column 3 . The percentage difference between the new model and AGMA values are indicated in column 4 . The variance between the results is higher for case 1 and very low for cases 2 and 3. The versions of AGMA straight bevel gear models used in the referred works are similar for cases 2 and 3 but is different for case 1 . The results from the new model are very close to the AGMA model results, suggesting that the new model may be considered reasonable. In the examples considered, it should be noted that the new model stresses are either slightly lower or somewhat lower than AGMA values.

Table 1: Input Parameters for Contact Stress for Cases 1 to 3

\begin{tabular}{|l|c|c|c|}
\hline \multirow{2}{*}{\multicolumn{1}{|c|}{ Parameters }} & \multicolumn{3}{|c|}{ Case } \\
\cline { 2 - 4 } & 1 & 2 & 3 \\
\hline Transmitted power $(\mathrm{kW})$ & 5.25 & 7.5 & 1.86 \\
\hline Pinion speed (rpm) & 1150 & 2500 & 600 \\
\hline Pinion torque (Nm) & 43.59 & 28.7 & 29.6 \\
\hline Speed ratio & 3.278 & 1.75 & 3.0 \\
\hline Pressure angle $\left({ }^{\circ}\right)$ & 20 & 20 & 20 \\
\hline Back end module (mm) & 4.23 & 3.18 & 3.18 \\
\hline Pinion teeth number & 18 & 20 & 16 \\
\hline Gear teeth number & 59 & 35 & 48 \\
\hline Pinion pitch diameter $(\mathrm{mm})$ & 76.19 & 63.5 & 50.8 \\
\hline Gear pitch diameter $(\mathrm{mm})$ & 249.75 & 111.13 & 152.4 \\
\hline Face width (mm) & 38.1 & 21.34 & 25.4 \\
\hline External overload factor & 1.0 & 1.0 & 1.5 \\
\hline Gear tooth quality number & 9 & 11 & 11 \\
\hline Service load factor & 1.710 & 2.025 & 2.258 \\
\hline
\end{tabular}

Table 2: Contact Stresses for Cases 1 to 3

\begin{tabular}{|c|c|c|c|}
\hline \multirow{2}{*}{ Case } & \multicolumn{3}{|c|}{ Contact Stress (MPa) } \\
\cline { 2 - 4 } & AGMA & New Model & $\begin{array}{c}\text { Difference } \\
(\mathbf{\%})\end{array}$ \\
\hline 1 & 593.7 & 454.64 & 23.42 \\
\hline 2 & 584.4 & 560.75 & 4.05 \\
\hline 3 & 672.3 & 656.2 & 2.40 \\
\hline
\end{tabular}




\section{DESIGN CAPACITY MODEL APPLICATIONS}

Applications of Eq. (26) for design sizing and Eq. (20) for design verifications are performed in this section. Two design cases are presented in which the basic dimensions of a gearset are determined, a design sizing task, and then checked for design adequacy in design verification. These two cases demonstrate how the new bevel gear contact fatigue capacity models are used in design analysis tasks. The problem statements in the design cases have been paraphrased and the design parameters have been converted to metric units where necessary by the authors.

\subsection{Design Case 4}

Design a right-angle bevel gearset of steel to transmit $5.25 \mathrm{~kW}$ with the pinion running at $1150 \mathrm{rpm}$ and gear at $350 \mathrm{rpm}$. The gear teeth pressure angle is $20^{\circ}$ and the drive and driven sources are considered uniform, that is, $K_{O}=1.0$ may be assumed. The desired design life is 1010 load cycles at a reliability of $99 \%$ and the gear teeth are to be crowned. The contact strength at the desired life is $831.5 \mathrm{MPa}$ and a design factor of 1.5 is desired for a gear tooth quality number 9 [2].

\subsection{Design Case 5}

A gearbox of right-angle bevel gearset is to be made of steel for a life of 20 years. The drive is to transmit $6 \mathrm{~kW}$ with the pinion running at $750 \mathrm{rpm}$ and a speed ratio of about 2.5 is desired. The prime mover is induction motor and the driven device is a belt conveyor: assume $K_{O}=1.75$. The pinion will be made of C45 (1045) steel of hardness $400 \mathrm{HVN}$ and the gear material is ductile iron grade 120-90-02, of hardness $350 \mathrm{HVN}$. A design factor of 1.2 is desired for contact stress. [27].

\subsection{Solutions for Cases 4 and 5}

Design case 4 is the same problem as case 2 above but framed for sizing. The design contact strength for this problem is specified but that for case 5 was determined on the basis of AGMA recommendations. Using the life information for the gearbox, the design contact strengths for the pinion and gears were estimated. The pinion was found to be weaker than the gear with estimated design contact strength of $880 \mathrm{MPa}$. Table 3 shows the summary of the design sizing parameters while Table 4 shows design verification data,

Table 3: Design Sizing for Cases 5 and 6

\begin{tabular}{|l|c|c|}
\hline \multirow{2}{*}{\multicolumn{1}{|c|}{ Parameter }} & \multicolumn{2}{c|}{ Value } \\
\cline { 2 - 3 } & Case 4 & Case 5 \\
\hline Transmitted power (kW) & 5.25 & 6.0 \\
\hline Pinion rotational speed (rpm) & 1150 & 750 \\
\hline Gear rotational speed (rpm) & 350 & 300 \\
\hline Desired speed ratio & 3.286 & 2.5 \\
\hline Pinion number of teeth & 21 & 22 \\
\hline Composite elastic modulus (GPa) & 230 & 230 \\
\hline Pinion torque (Nm) & 43.59 & 76.39 \\
\hline Design contact strength (MPa) & 831.5 & 880 \\
\hline Desired design factor & 1.5 & 1.2 \\
\hline External overload factor & 1.00 & 1.75 \\
\hline Service load factor & 1.597 & 2.927 \\
\hline Back end module (mm): estimate & 3.07 & 3.46 \\
\hline Back end module (mm): chosen & 3.0 & 4.0 \\
\hline
\end{tabular}

The design sizing estimate for the back end module was $3.07 \mathrm{~mm}$ for case 4 and a standard value of $3.0 \mathrm{~mm}$ was chosen $[6,28]$. The module of $3.0 \mathrm{~mm}$ was used in the first iteration during verification giving a design factor of 1.50 . This value is exactly what is desired hence the design is accepted as satisfactory. Effort and time savings are possible through the use of the dual approach of design sizing and design verification as only one iteration is used here to achieve the desired goal. This approach eliminates much of the trial-and-error steps often used in gear design. The design sizing estimate of the back end module was $3.46 \mathrm{~mm}$ for case 5 , but a standard size of $3.5 \mathrm{~mm}$ was chosen. A gear tooth quality number of 10 was chosen for case 5 based on mid-plane pitch velocity. The estimated design factor is seen to be 1.20 which is the desired value. Therefore the design is accepted as adequate.

Table 4: Design Verification for Cases 5 and 6

\begin{tabular}{|l|c|c|}
\hline \multirow{2}{*}{\multicolumn{1}{|c|}{ Parameter }} & \multicolumn{2}{c|}{ Value } \\
\cline { 2 - 3 } & Case 4 & Case 5 \\
\hline Normal pressure angle $\left({ }^{\circ}\right)$ & 20 & 20 \\
\hline Back end module $(\mathrm{mm})$ & 3.0 & 3.5 \\
\hline Pinion teeth & 22 & 21 \\
\hline Gear teeth & 72 & 53 \\
\hline Design speed ratio & 3.27 & 2.52 \\
\hline Pinion pitch diameter $(\mathrm{mm})$ & 66 & 73.5 \\
\hline Gear pitch diameter $(\mathrm{mm})$ & 216 & 185.5 \\
\hline Pinion face width $(\mathrm{mm})$ & 32 & 30 \\
\hline Service load factor & 1.585 & 2.976 \\
\hline Contact stress (MPa) & 553.28 & 735.38 \\
\hline Estimated design factor & 1.50 & 1.20 \\
\hline
\end{tabular}

Comparison of the values of the service load factor estimates from Table 3 and Table 4 shows that the difference between the design verification and design sizing values are $0.76 \%$ and $-1.65 \%$ respectively, for design case 4 and design case 5 . The design verification service load factor was determined using AGMA approach, so it is considered more reliable. Since the differences in the estimates are small, the estimation scheme for design sizing appears reasonable in these examples.

\section{CONCLUSIONS}

The models presented in this paper are based on the Tredgold geometric approximation that provides a geometric link between a physical bevel gear and the equivalent or virtual spur gear. The use of the midplane radius of the physical bevel gear for force analysis is a close approximation [13] which is somewhat conservative. Based on this force analysis, a bevel load factor is defined that provides a kinetic link between the physical bevel gear and the virtual spur gear. The bevel load factor transfers the forces on the physical bevel gear to the virtual spur gear for contact stress analysis. Consequently, the contact stress on the virtual spur is being used to predict the contact stress on the physical bevel gear. The developed models are transparent in design parameters for contact stress capacity of straight bevel gears.

Three design cases of contact stress computations from different references were carried out and com- 
pared with AGMA estimates. Differences in results vary from $2.4 \%$ to $23.4 \%$, depending on the AGMA model version. A noticeable trend is that the new model estimates are usually lower than AGMA values. It is observed by Dudley [8] that bevel gears in practice appear to outperform predictions. Thus for such gears, the design models used may be somewhat conservative. Since the new model presented gives slightly lower contact stress values, it seems worthy of serious consideration. It should be noted that stress-life in gearing has a power-law relationship, so a small decrease in stress level can lead to a substantial inc-rease in gear life expectancy.

The new contact stress capacity model was modified for design sizing and its application is demonstrated in design cases 4 and 5. Design sizing task provides the value of the back end module based on contact fatigue which is used to determine the other basic dimensions of a straight bevel gearset. The design sizing model requires minimal design parameter input, the others are generated based on the inputs. Comparison of the service load factor values for design sizing and design verification indicates a difference of $0.76 \%$ in case 4 and $-1.65 \%$ in case 5 . This is a very close prediction which somewhat recommends the method used. Certainly, more design cases are necessary for further verification of the design approach presented, but it may be concluded from the results of the examples considered that the contact stress design capacity model presented appears reasonable.

\section{ACKNOWLEDGEMENTS}

The authors gratefully acknowledge that this study was supported in parts with funds from COSET Research Fund and the University Faculty Development Fund of Texas Southern University, Houston, Texas.

\section{REFERENCES}

[1] Bhandari, V. B. (2010), Design of Machine Elements, 3rd ed., McGraw Hill, India.

[2] Collins, J. A., Busby, H., Staab, G. H., (2010), Mechanical Design of Machine Elements and Machines: A Failure Prevention Perspective, 2nd ed., John Wiley and Sons, New York.

[3] Petrov, M., Chernilevsky, D., Berezovsky, Y. (1988), Machine Design, MIR, Moscow.

[4] Rothbart, H. A. \& Brown, T. H. (2006), Mechanical Design Handbook, 2 ${ }^{\text {nd }}$. ed., McGraw-Hill, New York.

[5] Joshi, H. D. \& Kothari, K. D., (2014), Mode and cause of failure of a Bevel gear-A review, Int'l Journal of Advance Engineering and Research Development (IJAERD), Volume 1 Issue 2, March 2014, e-ISSN: 2348 - 4470.

[6] Mott, R. L. (2004), Machine Elements in Mechanical Design, 4th ed. SI, Pearson Prentice Hall, New York.

[7] Shigley, J. E and Mischke, C. R. (Chief Editors), (1996), Standard Handbook of Machine Design, McGraw-Hill, New York.
[8] Dudley, D. W. (2009), Handbook of Practical Gear Design, CRC Press, Baca Raton.

[9] Raj, N. Mohan and Jayaraj, M., (2013): Design of Contact Stress Analysis in Straight Bevel Gear, International Journal of Computational Engineering Research, Vol-03, Issue-4.

[10] Broglie, M. J. \& Smith, D. F. (1992, Match/April), Gear Hardness Technology, Gear Technology.

[11] Stadtfeld, H. J, (2001, Feb.), The Basics of Spiral Bevel Gears, Gear Technology, pp. $31-38$.

[12] RoyMech, Gears-Gear Efficiency; http://www. roymech.co.uk/Useful_Tables/Drives/Gear_Efficie ny.html

[13] Maitra, G. M., (2013), Fundamentals of Toothed Gearing: Handbook of Gear Design, 2nd ed., McGraw Hill, New Delhi. Beach-Piping TB

[14] Gear Technical Reference - KHK Gears; http:// khkgears.net/wp-content/uploads/2015/10/gear_ guide.pdf.

[15]Bergseth, E. (2009), Influence of Gear Surface Roughness, Lubricant Viscosity and Quality Level on ISO 6336 Calculation of Surface Durability, Technical Report, Department of Machine Design, Royal Institute of Technology, Stockholm, https://www.diva-portal.org/smash/get/diva2:4897 51/FULLTEXT01.pdf

[16] Schmid, S. R., Hamrock, B. J. \& Jacobson,B. O., (2014), Fundamentals of Machine Elements, 3rd ed., CRC Press, New York.

[17] Savage, M. \& Mackulin, M. J. (1991), Maximum Life Spur Gear Design, NASA Technical Memorandum

[18] Mechanical Design Data Manual, Chap. 8, Spur and helical gears, http://www.learneasy.info /MDME/modules/7758D_Machine_Design/gears/ gears.pdf.

[19] Osakue, E., (2016), Simplified Spur Gear Design, Proceedings of International Mechanical Engineering Congress and Exposition 2015 MECE, Paper Number IMECE2016-65426, November 11-17, Phoenix Arizona, USA.

[20] Norton, R. L., (2000), Machine Design: An Integrated Approach, $2^{\text {nd }}$. ed., Prentice-Hall, Upper Saddle River, New Jersey.

[21] Moldovean, G., Gavrila, C., Butuc, Bianca, (2013), Fatigue Stress Calculation of Straight Bevel Gears Applied to a Photo Voltaic Tracking System, Annals of the Oradea University, Iss. \#1; http://www.imtuoradea.ro/auo.fmte/

[22] Osakue, E. E., Anetor, L. (2017A), Helical Gear Contact Fatigue Design by Spur Gear Equivalency, Int'l Journal of Research in Engineering and Technology, Vol. 06, Issue 02.

[23] Osakue, E. E., Anetor, L., Odetunde, C., (2015), Reliability-based Component Design, Proceedings of International Mechanical Engineering Congress and Exposition 2015 MECE, Paper Number IMECE2015-50700, November 13-19, Houston, Texas, USA. 
[24] Bausbacher, E., Hunt, H., (1993), Process Plant Layout and Design, PTR Prentice Hall, Upper Saddle River, New Jersey.

[25] AGMA 2001-D04; http://wp.kntu.ac.ir/asgari/ AGMA\%202001-D04.pdf.

[26] Gears and Gear Drives;

[27] http://www.regalpts.com/PowerTransmission

[28] Solutions/ProductFundamentals/gears2.pdf

[29] Gopinath, K., \& Mayuram, M. M., Module 2Gears, Lecture 14-Bevel gear Problems, http:// nptel.ac.in/courses/112106137/pdf/2_14.pdf

[30] Budynas, R. G. \& Nissbett, J. K., Shigley's Mechanical Engineering Design, 9th ed., McGraw Hill Education.

\section{NOMENCLATURE}

HVN Hardness: Vicker's Number

$P_{1} \quad$ Power transmitted by pinion $(\mathrm{kW})$

$T_{1} \quad$ Torque transmitted by pinion (Nm)

$N_{1} \quad$ Rotational speed of pinion (rpm)

$T_{2} \quad$ Torque transmitted by gear (Nm)

$\mathrm{N}_{2} \quad$ Rotational speed of gear (rpm)

$z_{1} \quad$ Number of teeth of pinion

$z_{2} \quad$ Number of teeth of gear

$F_{t}$

$r_{m 1}$

$r_{m 2}$

$r_{m}$

$d_{m}$

b

$F_{n}$

$F_{r}$

$F_{a}$

$r_{e}$

$d_{e}$

$d_{r}$

$L_{e}$

$r_{t}$

$d_{t}$

$d_{t 1}$

$d_{t 2}$

$C_{t}$

$b_{t}$

$E_{c}$

$E_{1}$

$E_{2}$

$S_{H}$

$S_{c}$

$n_{c}$

$n_{H}$

$m_{e}$

$m_{t}$

$k_{1}$

$k_{2}$

$K_{b}$

$K_{s}$

$K_{f}$

$K_{e}$

$K_{c}$
$K_{O} \quad$ Overload or application factor

$K_{m} \quad$ Mounting overload factor for gearset

$K_{m o} \quad$ Basic mounting factor

$K_{m o}^{\prime} \quad$ Initial basic mounting factor

$K_{m c} \quad$ Mouting overload factor for crowned gear

$K_{m c} \quad$ teeth

$K_{v s} \quad$ Internal overload factor for spur gear

$K_{v} \quad$ Internal dunamic load factor

$K_{r} \quad$ Rim flexibility factor

$K_{s}^{\prime} \quad$ Initial service load factor

$K_{v}^{\prime} \quad$ Initial internal overload factor

$K_{m}^{\prime} \quad$ Iinitial mounting overload factor

$z_{1} \quad$ Number of teeth on bevel pinion

$z_{2} \quad$ Number of teeth on bevel gear

$z_{t 1} \quad$ Number of teeth on equivalent spur pinion

$z_{t 2} \quad$ Number of teeth on equivalent spur gear

$\lambda_{b} \quad$ Face width factor

$\mu \quad$ Gear ratio

$\mu_{t} \quad$ Equivalent spur gear ratio

$\mu_{t o} \quad$ Inital value of $\mu_{t}$

Pressure angle (deg)

Transverse plane pressure angle (deg)

${ }^{t}{ }^{t} \quad$ Shaft angle (deg)

$\varphi_{1} \quad$ Pitch cone angle of pinion (deg)

$\varphi_{2} \quad$ Pitch cone angle of gear (deg)

$\varpi_{s} \quad$ Load sharing factor

$\varpi_{t} \quad$ Transverse plane contact ratio

$\varphi \quad$ Pitch cone angle of pinion or gear (deg)

$v_{1} \quad$ Poisson's ratio of pinion material

$v_{2} \quad$ Poisson's ratio of gear material

$\rho_{t} \quad$ Composite radius of curvature of equivalent

spur gear $(\mathrm{mm})$

$\sigma_{H} \quad$ Hertz contact stress $(\mathrm{MPa})$

\section{ПРОЈЕКТОВАЊЕ ПРАВОЗУБИХ КОНУСНИХ ЗУПЧАНИКА ОТПОРНИХ НА ПИТИНГ}

\section{Е.Е. Осакуе, Л. Анетор}

Приказан је транспарентан модел величине контактног напона код правозубих конусних зупчаника, израђен на основу Тредголдове геометријске апроксимације. Дефинисан је фактор оптерећења конуса који обезбеђује кинетичку везу између физичког конусног зупчаника и виртуелног цилиндричног зупчаника. Приказан је прорачун контактног напона за три случаја пројектовања зупчаника из различитих референци и извршено је упоређивање са AGMA проценама. Разлике у добијеним резултатима се крећу од $2,4 \%$ до $23,4 \%$ са проценама нових модела, које су обично ниже од AGMA вредности. Верзија пројекта одређивања димензија новог модела примењена је на два случаја. Поређење вредности фактора оптерећења у радним условима при одређивању димензија код пројектовања зупчаника и верификације пројекта показује разлику од $0,76 \%$ у случају 4 и $-1,65 \%$ у случају 5. Иако је за даљу верификацију приступа пројектовању потребно приказати још случајева, може се закључити да је модел пројектовања прихватљив. 


\section{APPENDIX:}

\section{A1.0 Load Shearing Factor}

Generally, load sharing in gear transmission can be enhanced by wear-in and accurate manufacture of gear teeth. Low manufacturing accuracy and high hardness of gear teeth reduce load sharing. Inaccurate lowhardness gears may wear-in and cold-flow enough to develop relatively good contact patterns and load shearing early in their service life. Usually, helical and bevel gears are made accurate enough for load sharing to occur [8].

The number of teeth on the virtual spur gearset for straight bevel gears is estimated as:

$$
z_{t 1}=\frac{z_{1}}{\cos \phi_{1}} \quad z_{t 2}=\frac{z_{2}}{\cos \phi_{2}}
$$

The transverse contact ratio of the virtual spur gear for a straight bevel gear may be estimated as:

$$
\begin{aligned}
\varpi_{t}= & \frac{\sqrt{\left(r_{t 1}+m_{t}\right)^{2}-\left(r_{t 1} \cos \varphi_{t}\right)^{2}}}{\pi m_{t} \cos \varphi_{t}} \\
& +\frac{\sqrt{\left(r_{t 2}+m_{t}\right)^{2}-\left(r_{t 2} \cos \varphi_{t}\right)^{2}}}{\pi m_{t} \cos \varphi_{t}}-\frac{C_{t} \sin \varphi_{t}}{\pi m_{t} \cos \varphi_{t}}
\end{aligned}
$$

Define $k_{1}$ and $k_{2}$ :

$$
\begin{aligned}
& k_{1}=\sqrt{\left(z_{t 1}+2\right)^{2}-\left(z_{t 1} \cos \varphi_{t}\right)^{2}}-z_{t 1} \sin \varphi_{t} \\
& k_{2}=\sqrt{\left(z_{t 2}+2\right)^{2}-\left(z_{t 2} \cos \varphi_{t}\right)^{2}}-z_{t 2} \sin \varphi_{t}
\end{aligned}
$$

Then

$$
\varpi_{t}=\frac{k_{1}+k_{2}}{2 \pi \cos \varphi_{t}}
$$

The load sharing factor is estimated as [22]:

$$
\varpi_{s}=0.5\left(\varpi_{t}+1\right)
$$

\section{A2.0 Estimation of Service Load Factor}

The service load factor is used to account for load increases during normal operations of the gearset. It takes care of load excitations beyond the rated value that are reoccurring in nature and represents a magnification factor for the rated load in a gear design problem.

\section{A2.1 Design Sizing}

The estimate of the service load factor for design sizing task may be obtained as:

$$
K_{s}^{\prime} \approx 1.1 K_{o} K_{v}^{\prime} K_{m}^{\prime}
$$

\section{A2.1.1 External Overload Factor, $K_{O}$}

This also called application factor by some authors. It accounts for nominal load increases due to the interactive dynamics of a power source and a driven device. AGMA has recommendations.

\section{A2.1.2 Internal Overload Factor $\left(K_{v}^{\prime}\right)$}

A suggestion is made in [16] for an expression for a initial estimate of the mesh overload factor for cylindrical gears. A suggested modification of that expression for initial sizing of bevel gears is:

$$
K_{v}^{\prime} \approx 1+\lambda_{b}\left[0.40+0.03\left(T_{1}\right)^{1 / 3}\right] \leq 1.5
$$

\section{A2.1.3 Mesh Overload Factor $\left(K_{m}^{\prime}\right)$}

The gear mounting overload factor, $K_{m}$ takes care of non-uniform load distribution along the gear tooth width.

For design sizing tasks of bevel gears, it may be assumed that:

$$
K_{m}^{\prime} \approx K_{m o}^{\prime}+0.15 \lambda_{b}
$$

Table A1: Basic Mounting Factor

\begin{tabular}{|l|c|}
\hline Gear Mounting Type & Basic Mesh Overload Factor $\left(\boldsymbol{K}_{\boldsymbol{m o}}^{\prime}\right)$ \\
\hline Both gears straddled & 1.05 \\
\hline One gear straddled & 1.15 \\
\hline Both gears cantilevered & 1.30 \\
\hline
\end{tabular}

\section{A2.2 Design Verification}

The estimate of the service load factor for design verification task may be obtained as:

$$
K_{s}=K_{o} K_{v} K_{m} K_{c}
$$

\section{A2.2.1 Internal Overload Factor, $K_{v}$}

The internal overload factor, $K_{v}$ accounts for load excitations caused by non-conjugate actions of meshing gears, backlash, profile, pitch, etc. errors, dynamic imbalance, and shaft misalignment. It can be estimated based on AGMA recommendations for spur gears. Straight bevel gears generally exhibit higher noise level than spur gears in operation, limiting their applications to lower pitch point velocity than spur gears. Therefore, it may be argued that higher internal load is generated in straight bevel gears than spur gears at the same pitch point velocity. No definitive numerical estimate of such increase appears available at the present, so we assume:

$$
K_{v}=K_{v s}
$$

\section{A2.2.2 Mesh Overload Factor, $K_{m}$}

The mesh or mounting overload factor, $K_{m}$ takes care of non-uniform load distribution along the tooth contact length due to misalignment resulting from the rigidity of and clearances in gear supporting members like bearings, shafts, and housing; manufacturing accuracy, tooth width and spacing, and geometric characteristics of gear tooth. Based on AGMA graphs the ge-ar mounting overload factor may be approximated as: 
For $b \leq 125 \mathrm{~mm}$ :

$K_{m c}=K_{m c}+7.874 b \times 10^{-4}$

For $125 \mathrm{~mm}<b<356 \mathrm{~mm}$ :

$K_{m c}=K_{m o}+2.406(b-125) \times 10^{-3}$

For crowned gear teeth:

$$
K_{m}=K_{m c}
$$

For uncrowned teeth higher values are expected [20] and may be estimated as:

$$
K_{m}=2 K_{m c}-1
$$

Table A2 gives suggested values of $K_{m o}$.
Table A2: Basic mounting Factor for Right Angle Crowned Bevel Gearset [2, p. 667]

\begin{tabular}{|l|c|c|}
\hline \multirow{2}{*}{$\begin{array}{c}\text { Gear Mounting } \\
\text { Type }\end{array}$} & \multicolumn{2}{|c|}{ Basic Mesh Overload Factor $\left(\boldsymbol{K}_{\boldsymbol{m} \boldsymbol{o}}\right)$} \\
\cline { 2 - 3 } & $\mathrm{b} \leq 125 \mathrm{~mm}$ & $125 \mathrm{~mm}<\mathrm{b}<356 \mathrm{~mm}$ \\
\hline $\begin{array}{l}\text { Both gears } \\
\text { straddled }\end{array}$ & 1.00 & 1.10 \\
\hline One gear straddled & 1.10 & 1.20 \\
\hline $\begin{array}{l}\text { Both gears } \\
\text { cantilevered }\end{array}$ & 1.25 & 1.35 \\
\hline
\end{tabular}

\section{A2.2.3 Contact Quality Factor $\left(K_{c}\right)$}

Contact quality factor accounts for miscellaneous factors affecting contact integrity in a gear mesh. A value of 1.1 was suggested for spur gears [19] and will be adopted for straight bevel gears. 